\title{
ZOEAL MORPHOLOGY OF PACHYGRAPSUS TRANSVERSUS (GIBBES) (DECAPODA, GRAPSIDAE) REARED IN THE LABORATORY
}

\author{
Ana Luiza Brossi-Garcia ${ }^{1}$ \\ Misael Domingues Rodrigues ${ }^{2}$
}

\begin{abstract}
Ovigerous females of Pachygrapsus transversus (Gibbes, 1850) were collected on the Praia Dura and Saco da Ribeira beaches, Ubatuba, São Paulo, Brazil. Larvae were individually reared in a climatic room at $25^{\circ} \mathrm{C}$ temperature, salinities of 28,32 and $35 \%$ and under natural photoperiod conditions. The best rearing results were observed at $35 \%$ salinity. Seven zoeal instars were observed, drawing and described in detail. The data are compared with those obtained for $P$. gracilis (Saussure, 1858).

KEY WORDS. Grapsidae, Pachygrapsus transversus, larval development, decapod
\end{abstract}

The genus Pachygrapsus Randall, 1840 is represented by three species along the Brazilian littoral: P. corrugatus (von Martens, 1872), P. transversus (Gibbes, 1850 ) and $P$. gracilis (Saussure, 1858), the latter having been recorded for the first time in the state of São Paulo, Brazil, by Rodrigues \& BRossi-Garcia (1989) in rocky and sandy-muddy substrates together with $P$. transversus. This species and $P$. gracilis are quite similar and the traits most often utilized for specific identification have been indicated by RoDrigues \& BROSSI-GARCIA (1989).

The larval ontogeny of the family Grapsidae is little known. According to CHACE (1951), less than 15\% of the species have been studied from this viewpoint.

The main objective of the present investigation was to study the larval development of $P$. transversus reared in the laboratory and to characterize the plankton phase of life of this species. A detailed anatomical study of each instar was performed by verifying all the morphologic variations occurring during metamorphosis. The time intervals between successive ecdysis were also determined, and a comparative analysis between $P$. transversus and $P$. gracilis, whose larval morphology was described by BROSSI-GARCIA \& RODRIGUES (1993), was finally performed.

Other non-Brazilian species of the genus Pachygrapsus whose larval instars are known are: P. marmoratus (Fabricius, 1878), P. crassipes Randall, 1840 and $P$. maurus (Lucas, 1846) studied by CANO (1891), SCHLOTTERBECK (1976) and CUESTA \& RODRIGUES (1994), respectively.

1) Departamento de Zoologia, Instituto de Biociências, Universidade Estadual Paulista. Caixa Postal 199, 13506-900 Rio Claro, São Paulo, Brasil.

E-mail: bgarcia@cparetianas.com.br.

2) Departamento de Biologia Animal e Vegetal, Universidade Estadual de Londrina. Caixa Postal 6001, 86051-990 Londrina, Brasil.

E-mail: misael@npd.uel.br. 


\section{MATERIAL AND METHODS}

Ovigerous females of Pachygrapsus transversus were periodically collected on the Praia Dura and Saco do Ribeira beaches, municipality of Ubatuba $\left(23^{\circ} 26^{\prime} 14^{\prime \prime} \mathrm{S}, 45^{\circ} 05^{\prime} 9^{\prime \prime} \mathrm{W}\right)$ from muddy and rocky substrates. In the laboratory, the animals were maintained in aquaria with seawater from the place of collection, submitted to continuous aeration, and fed chopped fish. Newly hatched larvae were transferred to small Petri dishes containing $20 \mathrm{ml}$ filtered sea water at salinities of 28,32 and $35 \%$ and placed in a climatic room at a temperature of $25^{\circ} \mathrm{C}$ under natural photoperiod conditions.

During the first month of rearing, zoeae were fed rotifers (Brachionus sp.) and Artemia sp. nauplii thereafter.

The water of the plates was renewed daily after verification of mortality and of changes in instar.

The drawings were made using a binocular light microscope fitted with a light camera. Exuviae or larvae were fixed in 1:1 alcohol: glycerine.

\section{RESULTS}

\section{GENERAL CONSIDERATIONS}

The zoeal development of $P$. transversus consisted of ten ecdysis at 35\%o salinity, eight ecdysis at $32 \%$ salinity, and three ecdysis at $28 \%$ salinity but only seven zoeal instars were morphologically identified. The duration and survival of larvae are presented in table I.

Table I. Pachygrapsus transversus. Duration and survival of zoeal stages. (X) Mean duration, in days, of each stage; (X), cumulative mean duration from eclosion; (S.D.) standard deviation; (D-D') minimum and maximum duration; (ni) number of larvae reared at different salinities; ( $n$ ) number of larvae; $(\dagger)$ number of dead larvae; $(S)$ percentage of survival from eclosion.

\begin{tabular}{|c|c|c|c|c|c|c|c|c|c|c|c|}
\hline & Ecdisis & 1 & II & III & IV & v & $\mathrm{VI}$ & VII & VIII & IX & $x$ \\
\hline \multirow{6}{*}{$\begin{array}{c}28 \% \\
n i=100\end{array}$} & $X e(X)$ & 7.0 & 7 & $8.5(22.5)$ & & & & & & & \\
\hline & S.D. & 4.6 & 5.12 & 5.24 & & & & & & & \\
\hline & D-D' & $15-2$ & $20-1$ & $15-2$ & & & & & & & \\
\hline & $n$ & 66 & 34 & 6 & & & & & & & \\
\hline & $\dagger$ & 34 & 32 & 28 & & & & & & & \\
\hline & s & 66 & 34 & 6 & & & & & & & \\
\hline \multirow{6}{*}{$\begin{array}{c}32 \% \\
n i=100\end{array}$} & $X e(X)$ & 8.81 & 12.18 & 15.14 & 8.6 & 9.5 & 7.33 & 10 & $8(71)$ & & \\
\hline & S.D. & 2.44 & 2.71 & 511 & 2.07 & 0.57 & 1.52 & 2.82 & 0 & & \\
\hline & D-D' & $5-19$ & $7-17$ & $7-22$ & $7-12$ & $9-10$ & $6-9$ & $8-12$ & 8 & & \\
\hline & $n$ & 37 & 11 & 7 & 5 & 4 & 3 & 2 & 2 & & \\
\hline & $\dagger$ & 63 & 26 & 4 & 2 & 1 & 1 & 1 & - & & \\
\hline & s & 37 & 11 & 7 & 5 & 4 & 3 & 2 & 2 & & \\
\hline \multirow{6}{*}{$\begin{array}{c}35 \% \\
n i=225\end{array}$} & $X e(X)$ & 14.50 & 11 & 10.47 & 10.72 & 9.4 & 10.2 & 8.5 & 8.37 & 6.5 & $9.5(113.7)$ \\
\hline & S.D. & 1.96 & 2.05 & 3.39 & 2.88 & 2.79 & 2.21 & 1.8 & 1.4 & 0.7 & 2.12 \\
\hline & $D-D^{\prime}$ & $12-19$ & $7-16$ & $7-23$ & $7-18$ & $3-17$ & $7-11$ & $6-27$ & $7-11$ & $6-7$ & $8-11$ \\
\hline & $n$ & 79 & 56 & 44 & 33 & 25 & 8 & 13 & 8 & 2 & 2 \\
\hline & $\dagger$ & 146 & 23 & 12 & 11 & 8 & 17 & 5 & 5 & 6 & - \\
\hline & s & 35.1 & 24.8 & 19.5 & 14.6 & 11.1 & 3.5 & 5.7 & 3.5 & 0.8 & 0.8 \\
\hline
\end{tabular}




\section{ZOEAL MORPHOLOGY}

\section{Zoea I}

A globose carapace $(0,80 \mathrm{~mm}$ length) with two spines, a dorsal one and a rostral one, of approximately the same size. Non-pedunculated eyes (Fig. 1-I). Abdomen with five segments whose posterolateral margins are slightly acuminate. Fourth abdominal segment larger than the remaining ones. Second and third segments with a pair of dorsolateral saliences. Rectangular telson with a concave posterior margin and six plumose setae (Fig. 2-I).

Antennule (Fig. 3-I). Conical, without segmentation, with two aesthetascs and one simple seta.

Antenna (Fig. 3-II). Unirreme. Distal end with diminutive spines.

Mandible (Fig. 3-III). Strongly chitinous with cutting incisor and molar processes. Absent palp.

Maxillule (Fig. 3-IV). Bisegmented endopod with four plumose setae on the apical segment. Basal endite with five cuspidate setae and coxal endite with five plumose setae.

Maxilla (Fig. 3-V). Scaphognathite with four plumose setae. Endopod with four plumose setae, two of them distal and two subdistal. Bilobate basal and coxal endites with at least four plumose setae on each lobe.

First maxilliped (Fig. 3-VI). Bisegmented exopod with four long plumose setae on the distal segment. Endopod with five segments and 1-1-1-2-4 plumose setae from the proximal to the distal segment.

Second maxilliped (Fig. 3-VII). Exopod identical to that of the first maxilliped. Endopod with three segments and four plumose setae on the distal segment.

\section{Zoea II}

Carapace $(0.96 \mathrm{~mm}$ length) with one pair of small lateral spines.Abdomen and telson identical to that of zoea I (Figs 1, 2-II).

Antennule (Fig. 4-I). Identical to that of the previous instar.

Antenna (Fig. 4-II). Very similar to that of the previous instar, but with a larger number of spines.

Mandible (Fig. 4-III). Identical to that of zoea I.

Maxillule (Fig. 4-IV). Endopod with two plumose setae on the distal segment and one on the proximal segment. Basal endite with six cuspidate setae and one simple seta. Coxal endite with six plumose setae.

Maxilla (Fig. 4-V). Scaphognathite with four long plumose setae. Endopod identical to that of the previous instar. Basal and coxal endites with five plumose setae on each distal and proximal lobe.

First maxilliped (Fig. 4-VI). Exopod with six long plumose setae on the distal segment. Endopod with 1-0-1-2-4 plumose setae from the proximal to the distal segment.

Second maxilliped (Fig. 4-VII). Exopod identical to that of first maxilliped. Endopod with five plumose setae on the distal segment and one seta on the median segment. 


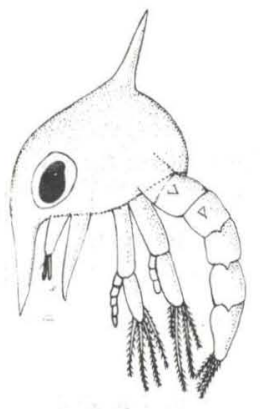

I

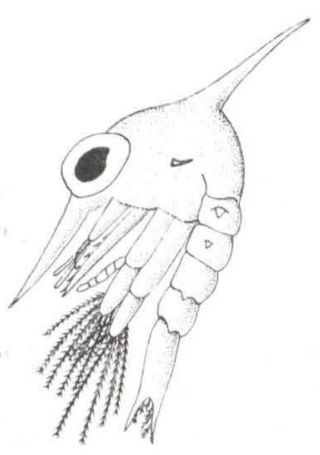

II
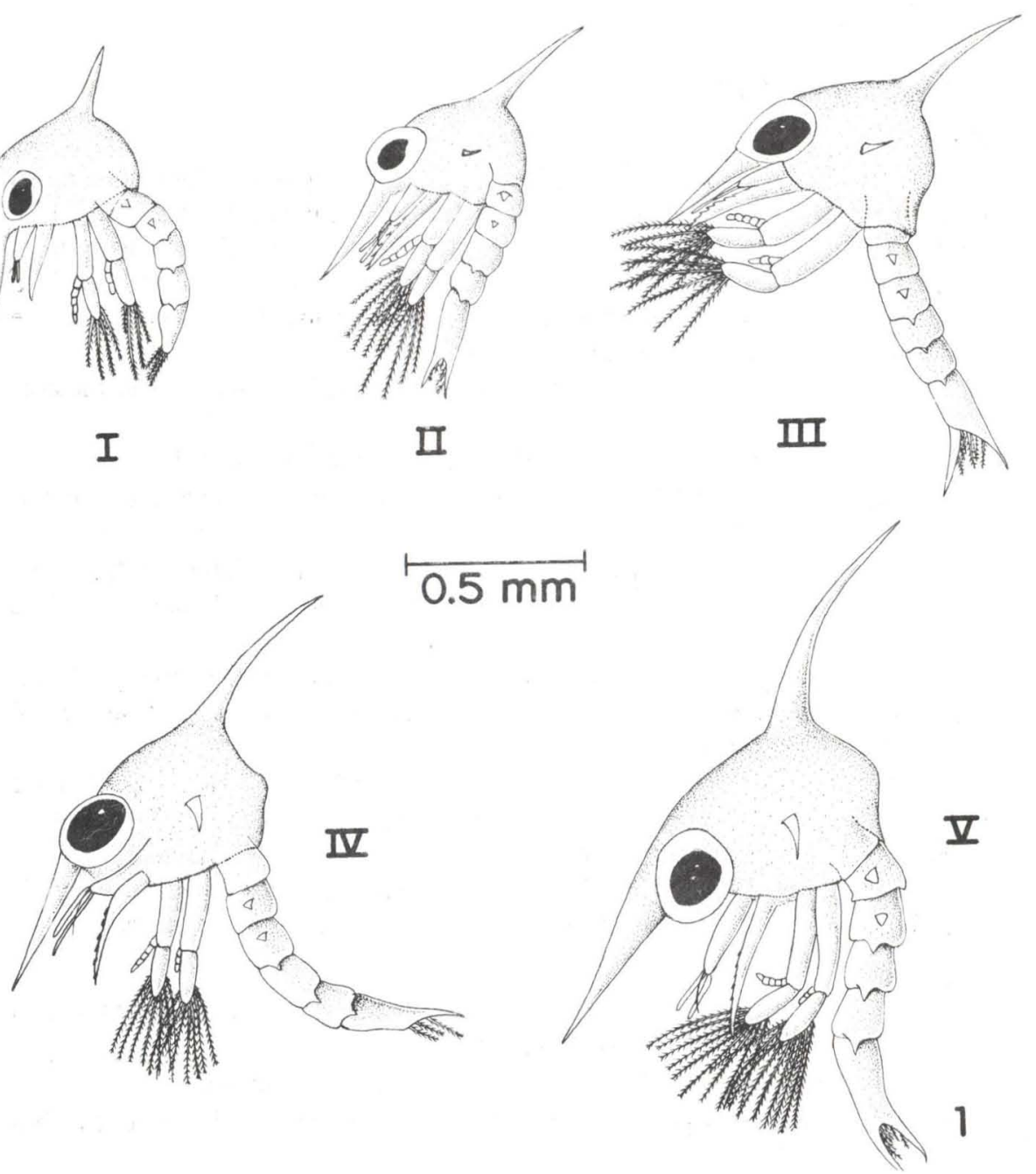

Fig. 1. Pachygrapsus tranversus. Lateral view of zoeal stages I to $\mathrm{V}$.

\section{Zoea III}

Carapace (1.15 mm length) with a long rostral and dorsal spine and a pair of small lateral spines. Abdomen and telson equal to that of zoea II (Figs 1, 2-III).

Antennule (Fig. 5-I). Unirreme with 1(2) aesthetascs and one simple seta.

Antenna (Fig. 5-II). Unchanged in relation to the previous instars.

Mandible (Fig. 5-III). Longer than wider, with barely dentate incisor and molar processes.

Maxillule (Fig. 5-IV). Endopod with five plumose setae on the distal segment. Basal endite with 5(6) cuspidate setae and 1(2) simple setae. Coxal endite with seven plumose setae. 


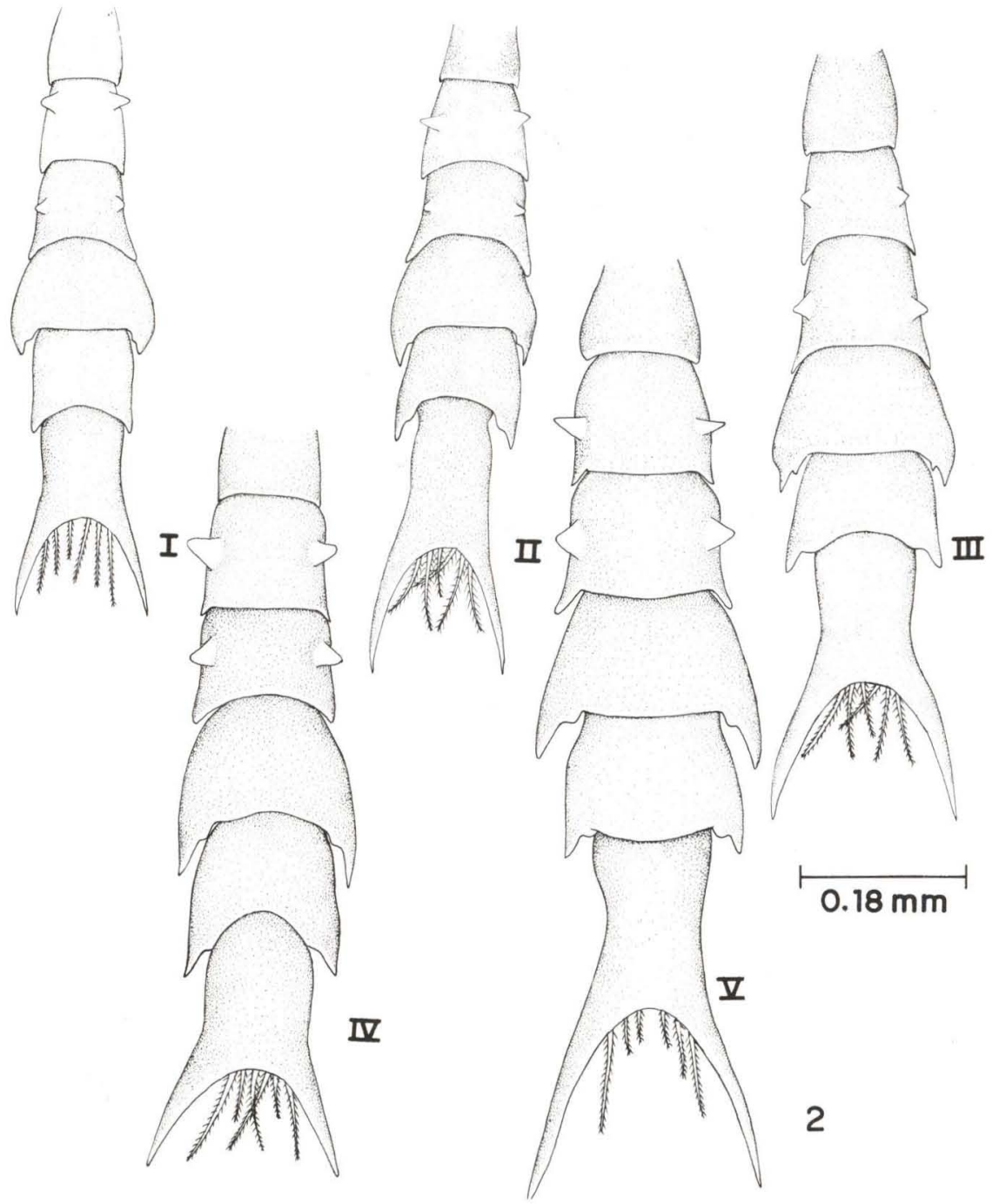

Fig. 2. Pachygrapsus transversus. Dorsal view of abdomen and telson of zoeal stages I to V.

Maxilla (Fig. 5-V). Scaphognathite with six long plumose setae. Endopod identical to that of the previous instars. Basal and coxal endites usually with 4(5) plumose setae each on the distal and proximal lobes.

First maxilliped (Fig. 5-VI). Exopod with seven long plumose setae. Endopod with $0(1)-0(1)-0(1)-1(2)-4$ plumose setae from the proximal to the distal segment.

Second maxilliped (Fig. 5-VII). Exopod identical to that of first maxilliped. Endopod with four setae on the distal segment. 

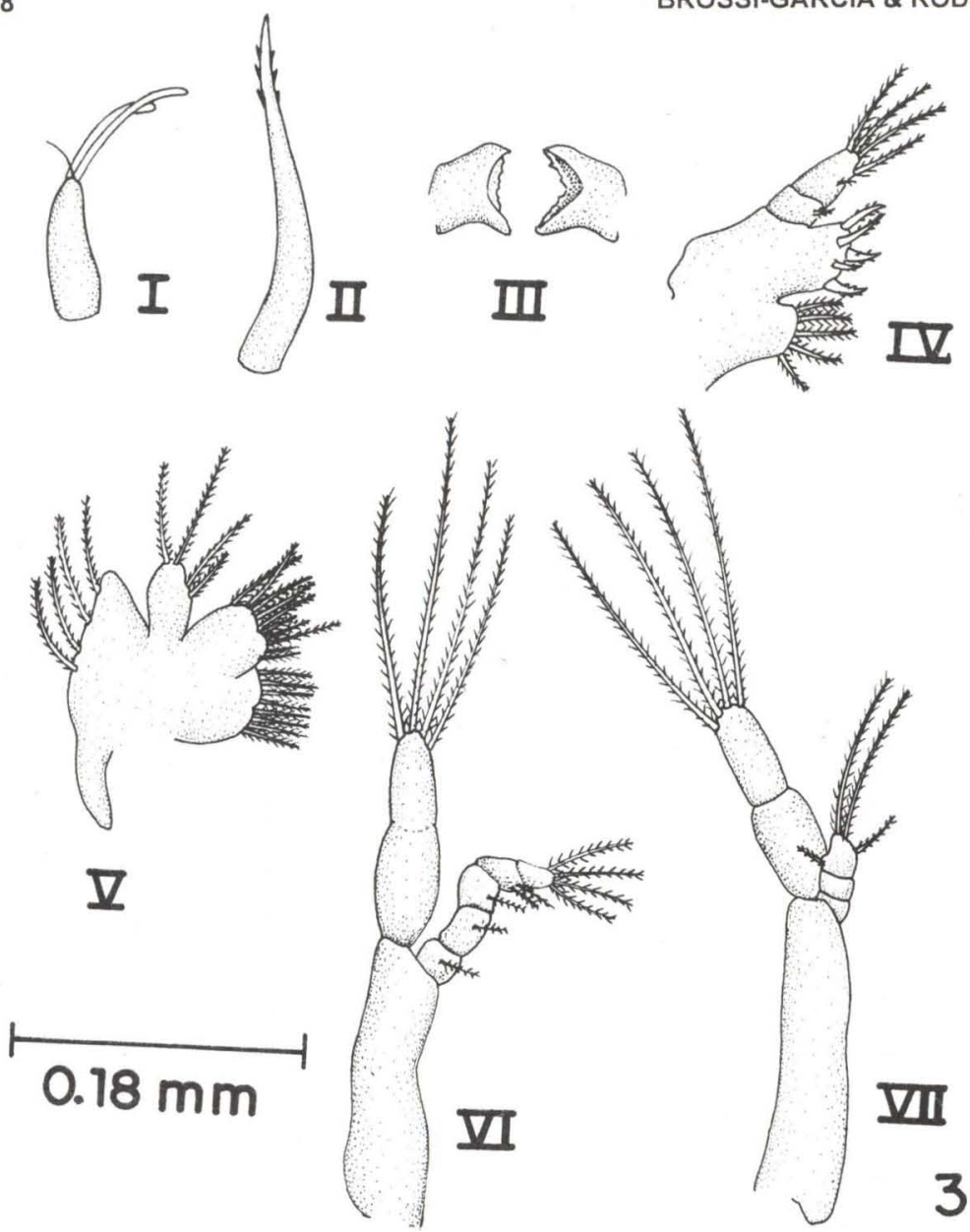

Fig. 3. Pachygrapsus transversus, zoea I. (I) Antenulle; (II) antenna; (III) mandible; (IV) maxillule; (V) maxilla; (VI) first maxilliped; (VII) second maxilliped.

\section{Zoea IV}

Identical to zoea III in terms on carapace shape (1.34 mm length), abdomen, telson (Figs 1, 2-V), antennule (Fig. 6-I), antenna (Fig. 6-II), and mandible (Fig. 6-III).

Maxillule (Fig. 6-IV). Endopod with four plumose setae on the distal segment. Basal endite with five cuspidate setae and two single setae. Coxal endite with six plumose setae.

Maxilla (Fig. 6-V). Scaphognathite with six long plumose setae. Endopod equal to the previous instars. Basal and coxal endites with the distal and proximal lobes containing three to five plumose setae each.

First maxilliped (Fig. 6-VI). Exopod with eight long plumose setae. Endopod with $0-1-0-3-3$ plumose setae. 
Second maxilliped (Fig. 6-VII). Endopod with 1-1-4 plumose setae from the proximal to the distal segment. Exopod identical to that of fist maxilliped.

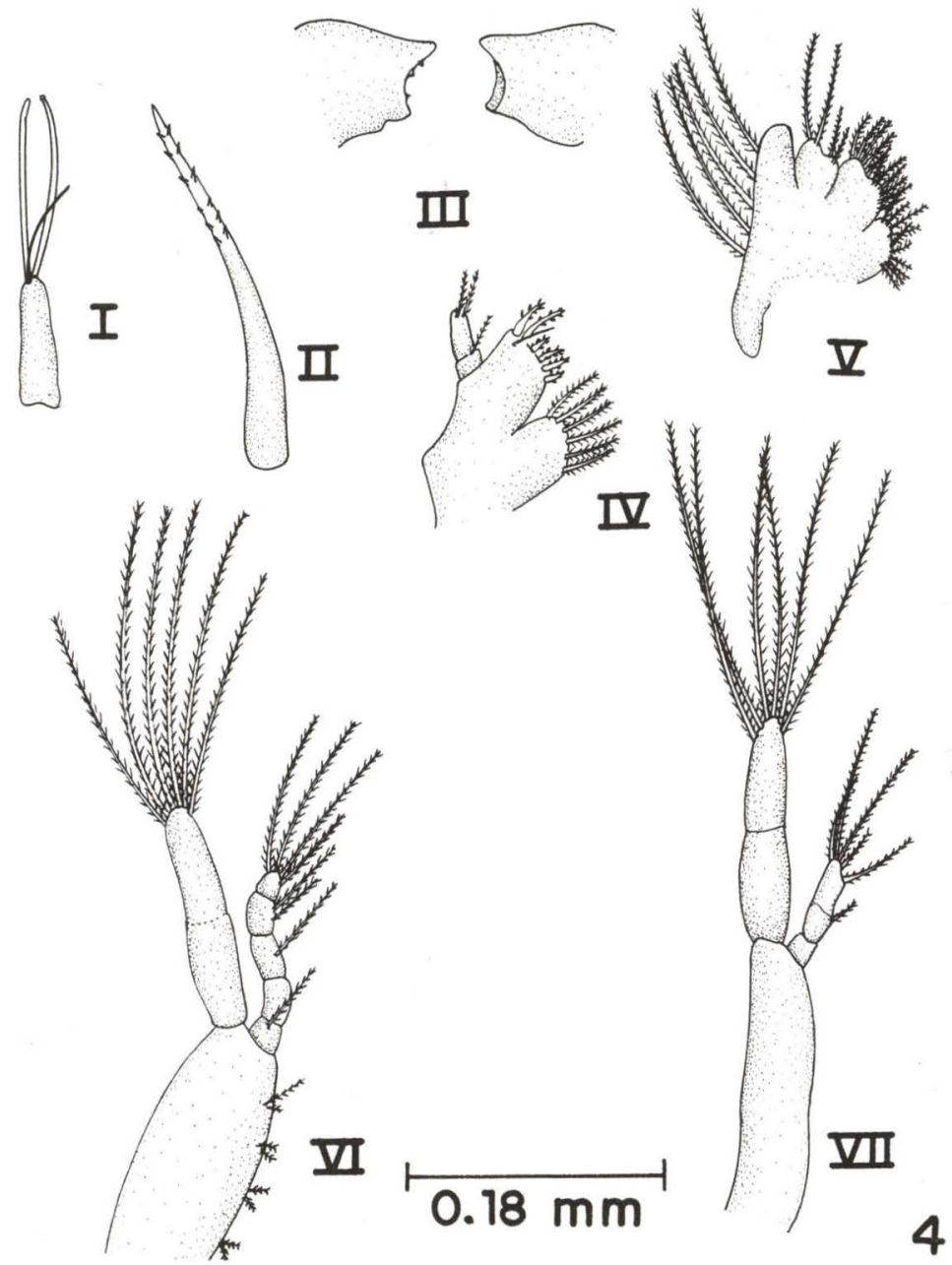

Fig. 4. Pachygrapsus transversus, zoea II. (I) Antenulle; (II) antenna; (III) mandible; (IV) maxillule; (V) maxilla; (VI) first maxilliped; (VII) second maxilliped.

\section{Zoea V}

Identical to zoea IV in terms of carapace (1.73 mm length), abdomen, telson (Figs 1, 2-V), antennule (Fig. 7-I), antenna (Fig. 7-II) and mandible (Fig. 7-III).

Maxillule (Fig. 7-IV). Endopod with four plumose setae on the distal segment. Basal endite with 5(6) cuspidate setae and 1(2) simple setae. Coxal endite with six plumose setae. 


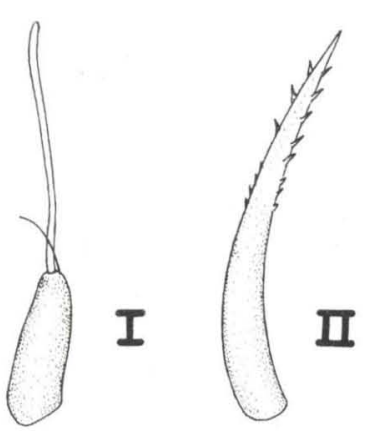

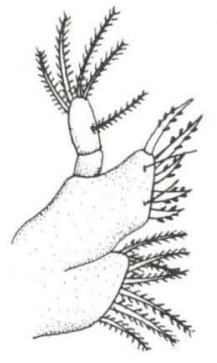

IV

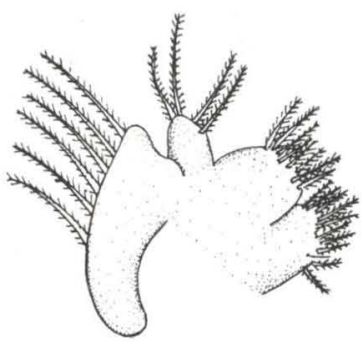

$\boldsymbol{\nabla}$
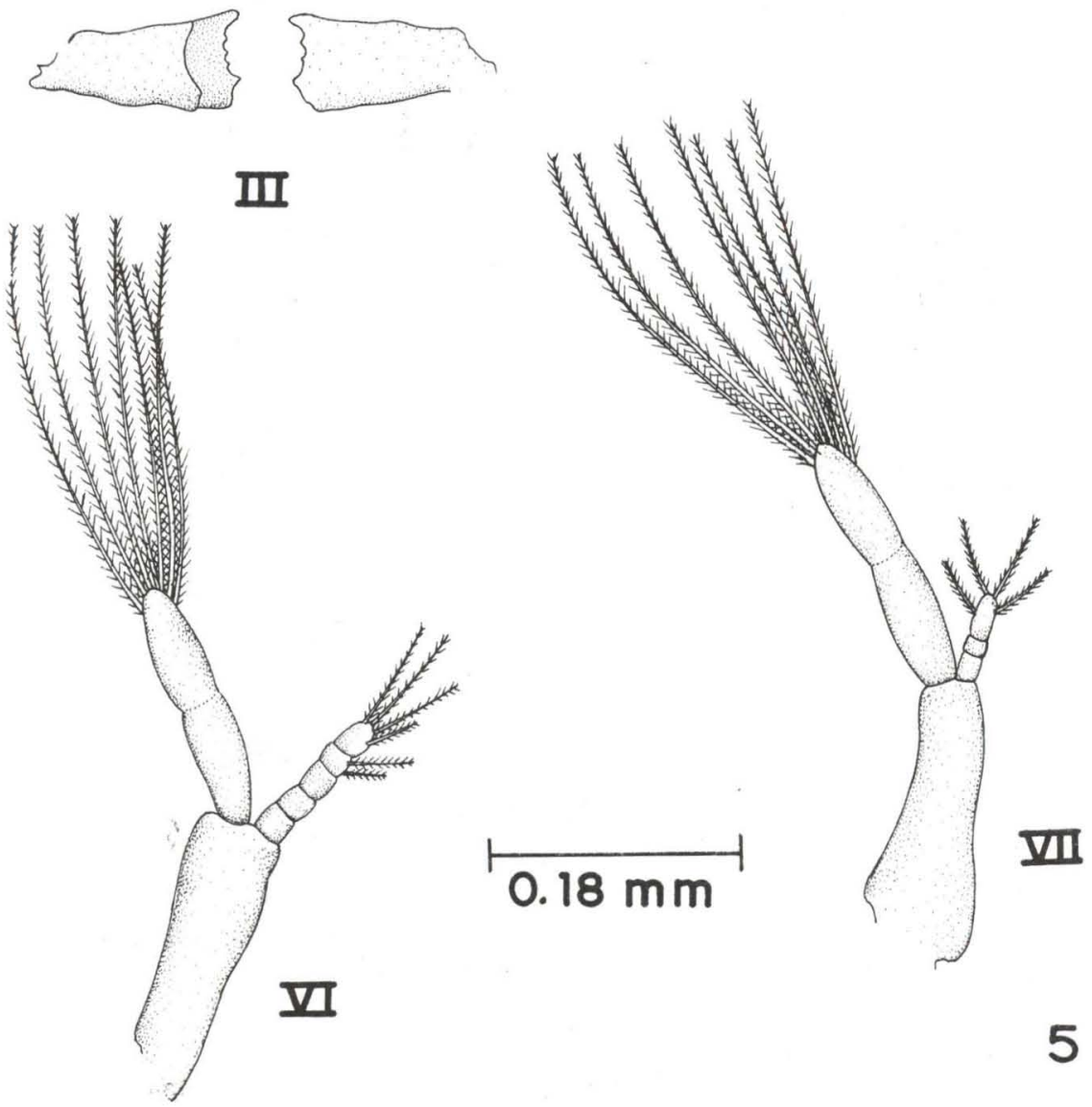

Fig. 5. Pachygrapsus transversus, third zoeal stage. (I) Antennule; (II) antenna; (III) mandible; (IV) maxillule; (V) maxilla; (VI) first maxilliped; (VII) second maxilliped. 

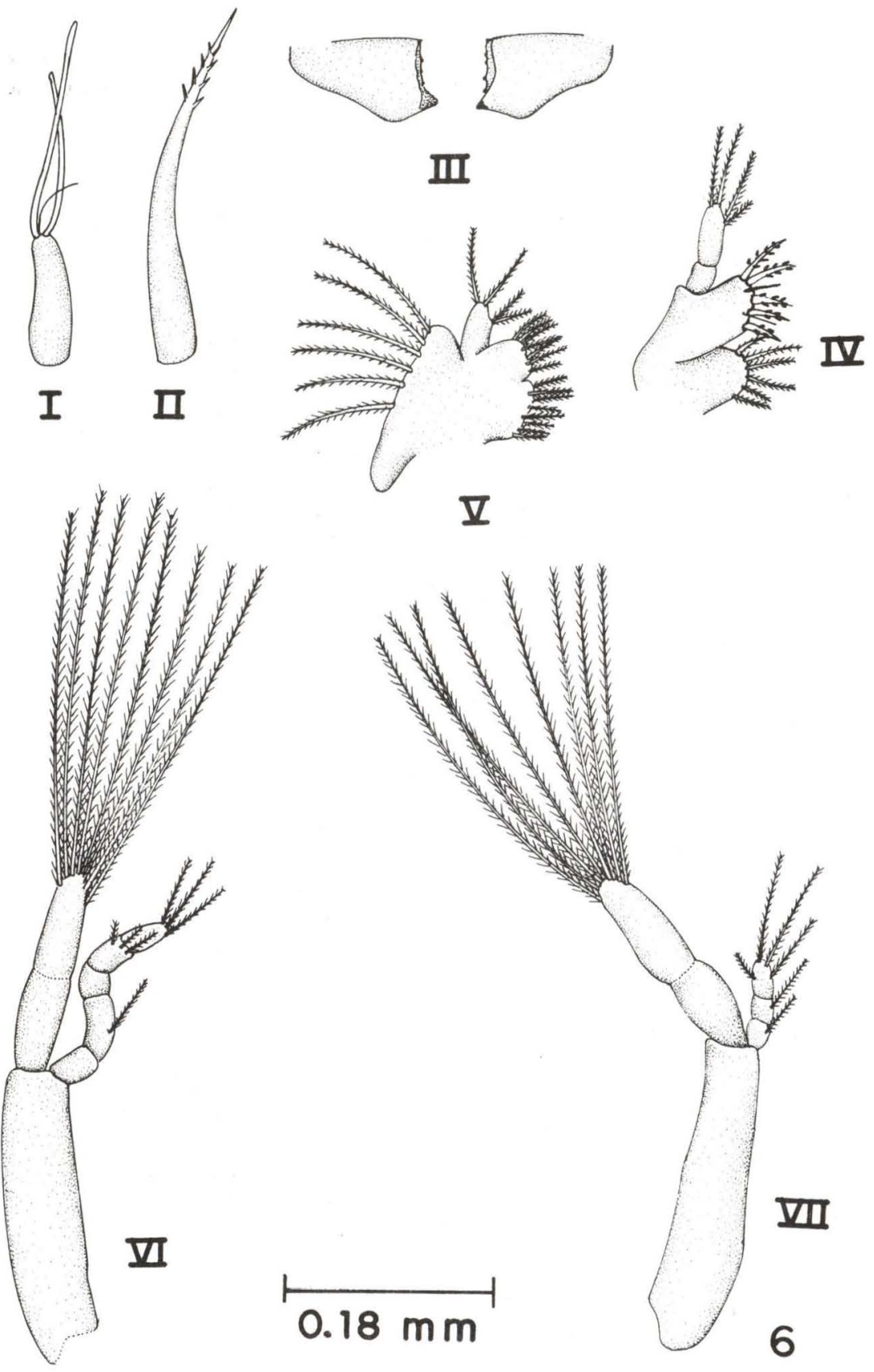

Fig. 6. Pachygrapsus transversus, fourth zoeal stage. (I) Antennule; (II) antenna; (III) mandible; (IV) maxillule; (V) maxilla; (VI) first maxilliped; (VII) second maxilliped. 
Maxilla (Fig. 7-V). Scaphognathite with approximately 15 plumose setae. Endopod with four. Basal and coxal endites with 4(5) plumose setae each on the distal and proximal lobes.

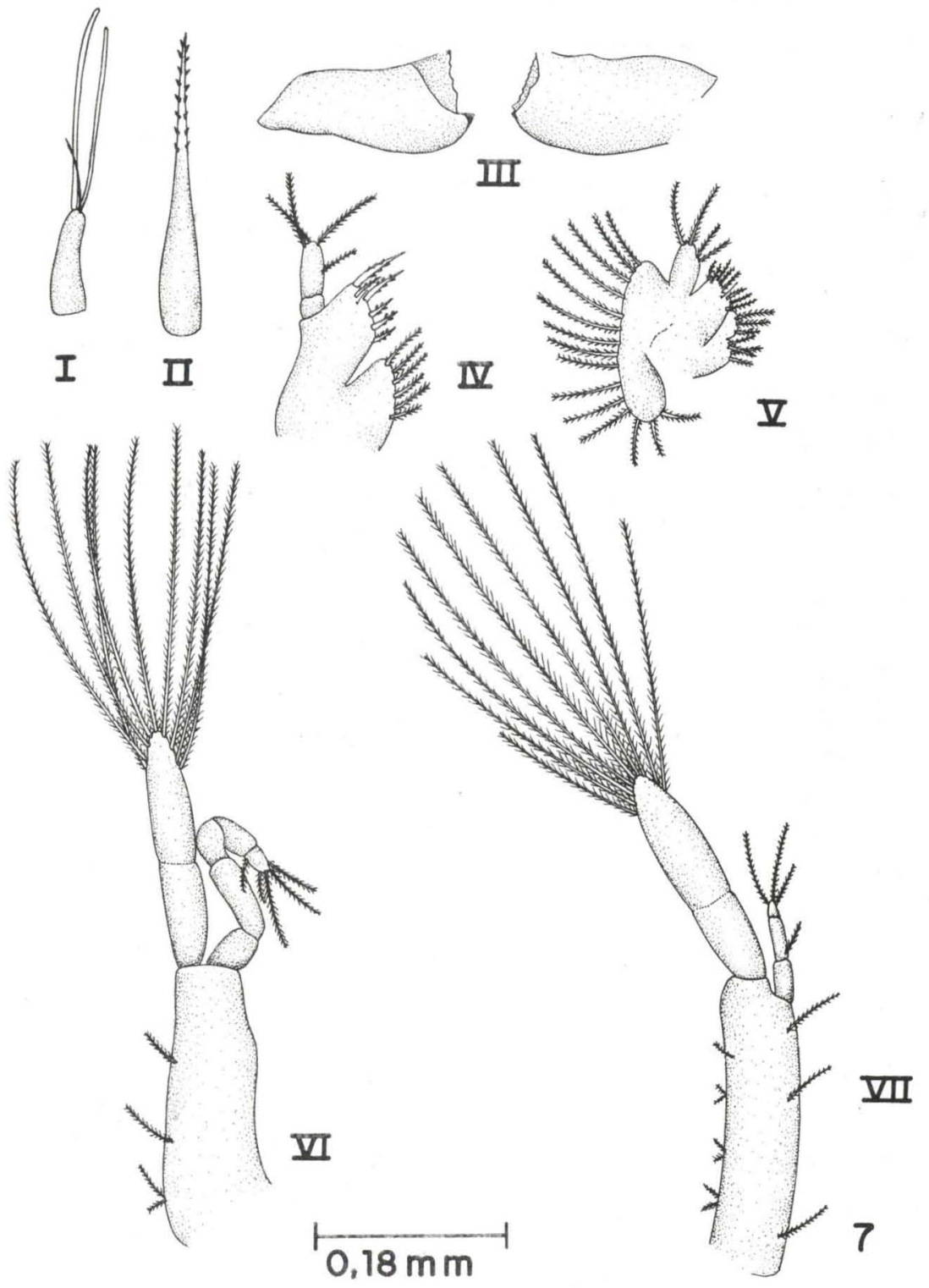

Fig. 7. Pachygrapsus transversus, fifth zoeal stage. (I) Antennule; (II) antenna; (III) mandible; (IV) maxillule; (V) maxilla; (VI) first maxilliped; (VII) second maxilliped. 


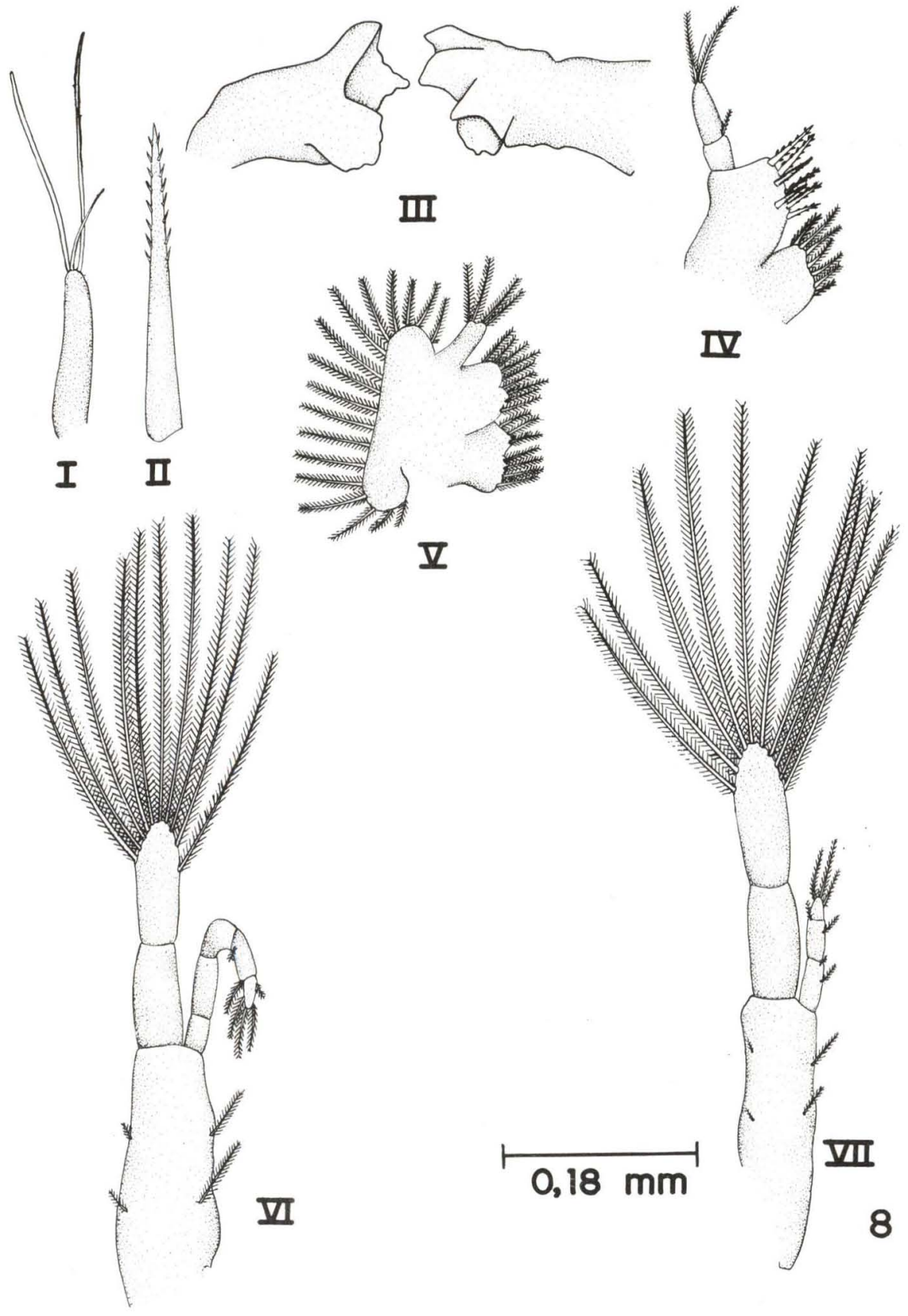

Fig. 8. Pachygrapsus transversus, Sixth zoeal stage. (I) Antennule; (II) antenna; (III) mandible; (IV) maxillule; (V) maxilla; (VI) first maxilliped; (VII) second maxilliped. 
First maxilliped (Fig. 7-VI). Exopod with nine long plumose setae on the distal segment. Endopod with five plumose setae on the distal segment.

Second maxilliped (Fig. 7-VII). Exopod with nine plumose setae and endopodite with 0-1-3 setae.

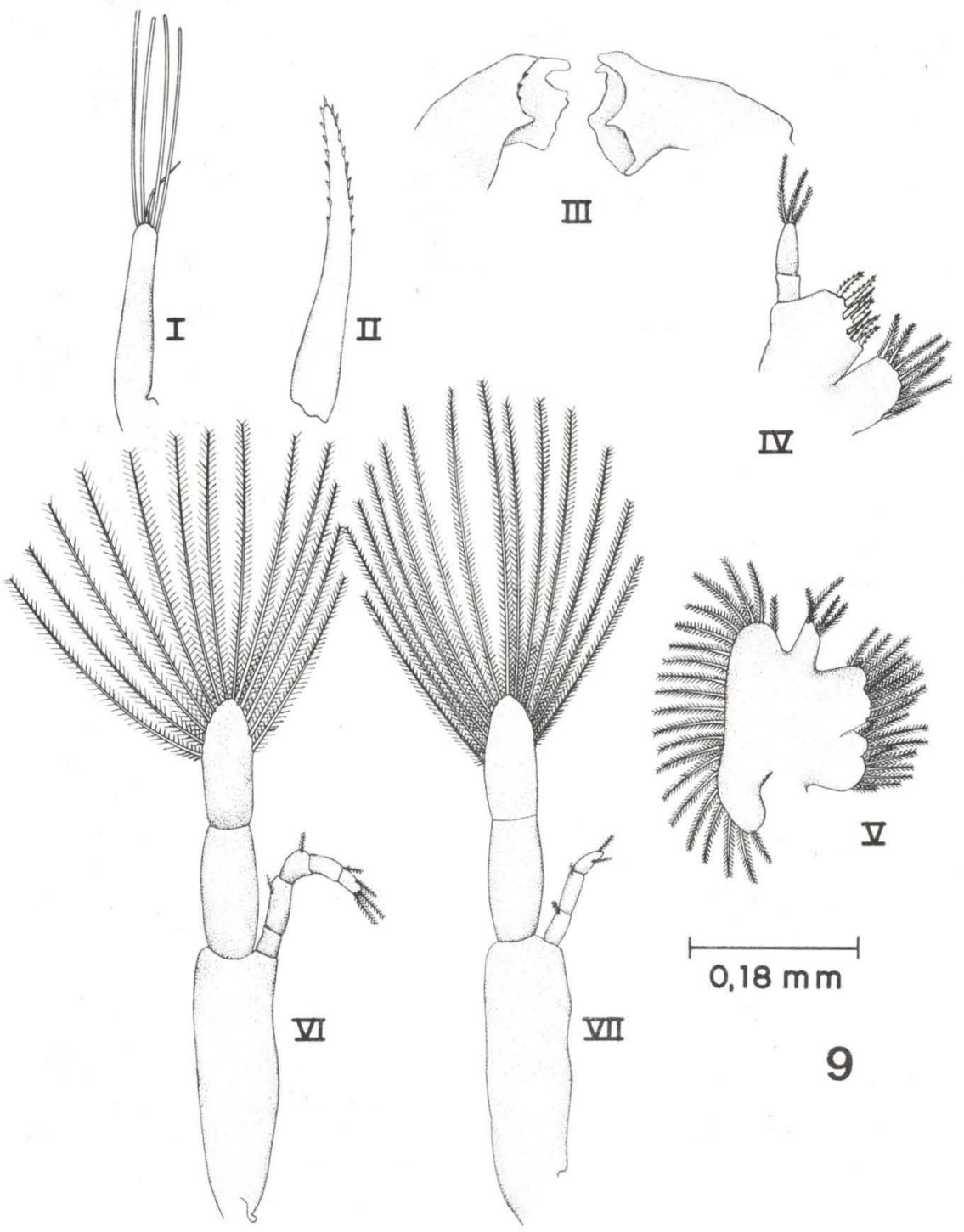

Fig. 9. Pachygrapsus transversus, seventh zoeal stage. (I) Antenulle; (II) antenna; (III) mandible; (IV) maxillule; (V) maxilla; (VI) first maxilliped; (VII) second maxilliped. 


\section{Zoea VI}

Abdomen, telson, antennule (Fig. 8-I), antenna (Fig. 8-II) and mandible (Fig. 8-III), identical to zoea V.

Maxillule (Fig. 8-IV). Basal endite with five cuspidate setae and 1(2) simple setae and coxal endite with seven plumose setae.

Maxilla (Fig. 8-V). Scaphognathite with approximately 17 plumose setae. Endopod like zoea V. Basal endite with 5(4) plumose setae respectively on the distal and proximal lobe. Coxal endite with 3(4) plumose setae on the distal and proximal lobes respectively.

First and second maxillipeds (Fig. 8-VI/VII). Exopod with 9(10) long plumose setae. Endopods of first and second maxillipeds with $0-0-0-1-5$ and $2-1-4$ setae, respectively.

\section{Zoea VII}

Abdomen, telson, antenna (Fig. 9-II) and mandible (Fig. 9-III) like to zoea VI.

Antennule (Fig. 9-I). With 4(5) aesthetascs and one simple seta.

Maxillule (Fig. 9-IV). Identical to zoea VI.

Maxilla (Fig. 9-V). Scaphognathite with 21(23) plumose setae.Basal endite with 4(5) plumose setae respectively on the distal and proximal lobes. Coxal endite with four plumose setae on the distal lobe and six on the proximal one.

First and second maxillipeds (Fig. 9-VI/VII). With 13(14) long plumose setae. Endopods of first and second maxillipeds with $0-1-1-0-4$ and 1-1-2 setae, respectively.

\section{DISCUSSION}

The family Grapsidae comprises four subfamilies and in Brazil is represented by 22 species.

As pointed out by BROSSI-GARCIA \& RODRIGUES (1993), the species known thus far of Plagusiinae, Varuninae and Grapsinae present five or six zoeal instars, and the species of the subfamily Sesarminae present four zoeal instars, although a variation from two to five may occur.

In this respect, the species studied thus far in Pachygrapsus are P. marmoratus, initially described by Cano (1891) and redescribed by HYMAN (1924) and the first zoeal instar described by PAULA (1985), P. crassipes whose first zoeal instar was initially described by VILlalobos (1971), and P. transversus, studied by LEBOUR (1944) also only in terms of the first zoeal instar.

Later, SCHLOTTERBECK (1976) redescribed the zoea I of $P$. crassipes and four more instars, i.e., up to zoea $\mathrm{V}$, which he obtained by rearing the animals in the laboratory at $16^{\circ} \mathrm{C}$ and at salinity of about $33 \%$. Although the megalopa instar was not observed in this study, the author seems to agree that the larval development of $P$. crassipes consists of about five zoeal instars and explains that the absence of a molt to the megalopa instar was possibly due to the relatively low water temperature $\left(16^{\circ} \mathrm{C}\right)$. 
As to $P$. marmoratus, there are descriptions and partial drawings of five zoeal instars, two megalopa instars which mainly differ in cephalothorax shape, and the first juvenile instar, whose aspect is that of an adult in miniature (HYMAN 1924). However, there is no information about the duration of metamorphosis or larval survival.

More recently, CUESTA \& RODRIGUES (1993) obtained five zoeal instars of $P$. marmoratus by rearing the animals in the laboratory. They also mentioned the occurrence of some intermediate instars between the third, fourth and fifth, as well as a supernumerary sixth instar. No megalopal instar was found. CUESTA \& Rodriguez (1994) described the first and second zoeal instars of Pachygrapsus maurus and Pachygrapsus transversus.

$P$. transversus (present paper), as well as $P$. gracilis (BRossi-Garcia \& RODRIGUES 1993) respectively presented 10 (99.16 days) and 13 (103 days) ecdysis obtained in the laboratory at $25^{\circ} \mathrm{C}$ and at $35 \%$ salinity for $P$. transversus and at $28^{\circ} \mathrm{C}$ and $34 \%$ salinity for $P$. gracilis. Seven zoeal stages, and a intermediate one between the sixth and seventh were mainly defined on the basis of larval size, number of setae on the basal and coxal endite of maxillule, number of setae on the scaphognathite of the maxilla and number of setae on the exopodite of maxillipeds.

Despite countless attempts to rear these species, the megalopa instar has not been obtained and the rudiments of the pleopods that characterize proximity to the megalopa were not observed up to the last zoeal instar observed.

The morphologic characterization of the family Grapsidae larvae has been mainly impaired by the extent of diversity observed in larval development.

AIKAWA (1929), based on the first zoeal instar of Brachyura, proposed a series of morphologic characteristics that were of systematic and/or phylogenetic importance for the group. Initially, the arrangement of the chromatophores, which, due to the lack of information in other studies, acquire secondary importance. Then, on the basis of relative exopod length in relation to the peduncle, the author distinguished four types of antenna (A, B, C and D), of which types B and C are the most typical of Grapsidae. In type B, the length of the exopod is $1 / 2$ to $3 / 4$ the length of the peduncle, and in type C, the exopod is very small, about less than $1 / 4$ the length of the peduncle. In the subfamilies Sesarminae and Varuninae, the antennae are of type B, and in Plagusiinae, of type C. In type A, the exopod and peduncle are of equivalent size, are considered to be more primitive and do not occur in Grapsidae. In type $\mathrm{D}$, considered to be a variation, there is no exopod and the peduncle is limited to a spiny process smaller than the rostrum or antennule. Another morphologic trait pointed out by AIKAWA (1929) was the type of telson. The most common of the six types (A, B, C, D, E and F), and which occur in Grapsidae, are types A and B. The telson of type $\mathrm{A}$ is triangular in shape with a well developed furca and 1-3 setae on each furca. The telson of type B is similar in shape to type A but its furca has no setae. Thus, the subfamilies are characterized as follows with respect to telson type: Grapsinae (A or B), Varuninae and Sesarminae (B) and Plagusiinae (A).

In addition to the above characteristics, AIKAWA (1929) also suggested analysis of the seta pattern of the maxilla and of the first and second maxillipeds and the presence or absence of spines on the carapace. 
With respect to Pachygrapsus, AIKAWA (1929) suggested a certain uniformity in the structure of the antenna, telson and carapace. According to HYMAN (1924), P. marmoratus does not exhibit lateral spines on the carapace. The telson has three spines on each side of the furca and, in zoea I, the antenna has a small exopodite which later becomes highly developed. Acording to LEBour (1944), P. transversus has no lateral spines on the carapace and its telson has two spines on each side of the furca and, in zoea I, the antenna has a small exopodite which later becomes highly developed. The antenna has diminutive setae on its distal portion. Pachygrapsus crassipes does not present lateral spines on the carapace in zoea I. These spines arise starting from zoea II. The telson has three setae on each side of the furca, and the exopod does not develop on the antenna (SCHLOTTERBECK 1976). Pachygrapsus gracilis and $P$. transversus present a telson of type A, i.e., triangular and with three setae on each side of the furca. In all the zoeal instars analyzed in these two species, the antenna is unirreme; there is no exopod development, falling into type D proposed by AIKAWA (1929) and in contrast to the typical shapes of the family Grapsidae. Finally, both in P. gracilis and in P. transversus, the lateral spines of the carapace are observable from zoea II and not from zoea III, as previously mentioned by BROSSI-GARCIA \& RODRIGUES (1993), agreeing in this respect with $P$. maurus and $P$. crassipes.

In general, $P$. gracilis and $P$. transversus brazilian larvae are extremely similar and can only be distinguished starting from the fourth instar by analysis of the following characteristics: size, number of aesthetascs of the antennules, number of cuspidate setae of the basal endites of the maxillules, and number of plumose setae on the scaphognathites of the maxillae (Tab. II).

Table II. Main morphological traits of the Pachygrapsus zoeal stages. (Aesthetascs) Number of aesthetascs of the antennule; (Cus. setae) number of cuspidate setae on the basal endite of the maxillule; (Plu. setae maxillule) number of the plumose setae on the coxal endite of the maxillule; (Plu. setae maxilla) number of the plumose setae on the scaphognathite of the maxilla; (Plu. setae $1^{\text {st }}$ maxilliped) number of the plumose setae on the exopod of the first maxilliped; (Plu. setae $2^{\text {nd }}$ maxilliped) number of the plumose setae on the exopod of the second maxilliped.

\begin{tabular}{|c|c|c|c|c|c|c|c|c|}
\hline Stages & Species & $\begin{array}{l}\text { Shield } \\
\text { length }\end{array}$ & Aesthetascs & Cus. setae & $\begin{array}{l}\text { Plu. setae } \\
\text { maxillule }\end{array}$ & $\begin{array}{l}\text { Plu. setae } \\
\text { maxilla }\end{array}$ & $\begin{array}{l}\text { Plu. setae } 1^{\text {st }} \\
\text { maxilliped }\end{array}$ & $\begin{array}{l}\text { Plu. setae } 2^{\text {nd }} \\
\text { maxilliped }\end{array}$ \\
\hline & P. gracilis & 0.75 & 2 & 5 or 6 & 5 & 4 & 4 & 4 \\
\hline & $P$. transversus & 0.80 & 2 & 5 & 5 & 4 & 4 & 4 \\
\hline \multirow[t]{6}{*}{ Zoea I } & P. crassipes & 0.90 & 2 & 5 & 6 & 4 & 4 & 4 \\
\hline & $P$. maurus & $0.85 \pm 0.02$ & 2 & 5 & 6 & 4 & 4 & 4 \\
\hline & P. marmoratus ${ }^{*}$ & $0.95 \pm 0.99$ & 3 & 5 & 6 & 4 & 4 & 4 \\
\hline & P. marmoratus & $0.83 \pm 0.02$ & 3 & & & & & \\
\hline & P. gracilis & 0.90 & 2 & 5 or 6 & 6 & 5 & 6 & 6 \\
\hline & $P$. transversus & 0.96 & 2 & 5 or 6 & 6 & 5 & 6 & 6 \\
\hline \multirow[t]{4}{*}{ Zoea II } & P. crassipes & 1.20 & 4 & 7 & 6 & 6 & 6 & 6 \\
\hline & $P$ maurus & $1.30 \pm 0.01$ & 4 & 7 & 6 & 5 & 6 & 6 \\
\hline & P. marmoratus & $1.20 \pm 0.02$ & & & & & & \\
\hline & P. gracilis & 1.08 & 2 & 7 & 7 & 6 & 7 & 7 \\
\hline \multirow[t]{2}{*}{ Zoea III } & P. transversus & 1.15 & 2 & 5 & 7 & 6 & 7 & 7 \\
\hline & P. crassipes & 1.50 & 1 & & 7 & 7 & 8 & 8 \\
\hline
\end{tabular}


Table II. Continued.

\begin{tabular}{|c|c|c|c|c|c|c|c|c|}
\hline Stages & Species & $\begin{array}{l}\text { Shield } \\
\text { length }\end{array}$ & Aesthetascs & Cus. setae & $\begin{array}{l}\text { Plu. setae } \\
\text { maxillule }\end{array}$ & $\begin{array}{l}\text { Plu. setae } \\
\text { maxilla }\end{array}$ & $\begin{array}{l}\text { Plu. setae } 1^{\text {st }} \\
\text { maxilliped }\end{array}$ & $\begin{array}{l}\text { Plu. setae } 2^{\text {nd }} \\
\text { maxilliped }\end{array}$ \\
\hline \multirow{3}{*}{ Zoea IV } & P. gracilis & 1.21 & 3 & 8 & 6 & $10(13)$ & 8 & 8 \\
\hline & P. transversus & 1.34 & 2 & 5 & 6 & 6 & 8 & 8 \\
\hline & P. crassipes & 1.75 & 4 & & 7 & 10 & 10 & 10 \\
\hline \multirow[t]{2}{*}{ Zoea V } & P. gracilis & 1.53 & 3 & 8 & 7 & $10(13)$ & 9 & 10 \\
\hline & 'P. transversus & 1.73 & 2 & 5 or 6 & 6 & 15 & 9 & 9 \\
\hline \multirow[t]{2}{*}{ Zoea VI } & P. gracilis & 1.73 & 4 & 8 & 6 or 7 & $15(17)$ & 9 & 10 \\
\hline & P. transversus & & 2 & 5 & 7 & $15(17)$ & 9 or 10 & 9 or 10 \\
\hline \multirow{2}{*}{$\begin{array}{l}\text { Intermediate } \\
\text { stage }\end{array}$} & P. gracilis & 1.90 & 4 & 9 & 6 & 20 & 10 & 11 \\
\hline & $P$. transversus & & 2 or 3 & 5 & 7 & 19 & 10 or 11 & 11 \\
\hline \multirow{2}{*}{ Zoea VII } & P. gracilis & 2.19 & 5 & 10 or 11 & 6 & $22(23)$ & 10 & 11 \\
\hline & P. transversus & & 4 or 5 & 5 & 7 & $21(23)$ & 13 or 14 & 13 or 14 \\
\hline
\end{tabular}

*. References: $P$. gracilis (Brossi-Garcia \& Rodrigues 1993); $P$. transversus (BRossi-Garcia \& Rodrigues present paper); $P$. crassipes (SCHOLTTERBECK 1976); $P$. marmoratus* (PAULA 1985); $P$. marmoratus and P. maurus (CUESTA \& RODRIGUES 1994); (T.T*) tip of the dorsal spine to the tip of the rostral spine.

ACKNOWLEDGEMENT. This work was supported by a research grant from Conselho Nacional de Desenvolvimento Cientifico e Tecnológico (CNPq).

\section{REFERENCES}

AIKAWA, H. 1929. On larval forms some Brachyura. Rec. Oceanogr. Work Jap. 2 (1): 17-55.

BRossi-GARCIA, A.L. \& M.D. RodRIGUES. 1993. Zoeal morphology of Pachygrapsus gracilis (Saussure, 1858) (Decapoda, Grapsidae) reared in the laboratory. Invert. Reprod. Dev. 24 (3): 197-204.

Cano, G. 1891. Sviluppo postembrionale dei Dorippidei, Leucosiadi, Corystoidei e Grapsidi. Mem. Soc. Ital. Sci. Nat. 8: 1-4.

CHACE JR., F.A. 1951. The number of species of decapod and stomatopod Crustacea. Jour. Wash. Acad. Sci. 41: 370-372.

Cuesta, J.A. \& A. Rodriguez. 1993. Larval development of Pachygrapsus marmoratus (Fabricius) (Brachyura, Grapsidae, Grapsinae) reared in the laboratory. Abst. Intern. Senckenberg Symp. Crust. Decap., Frankfurt: 18-22.

1994. Early zoeal stages of Pachygrapsus marmoratus (Fabricius), $P$. transversus (Gibbes) and P. maurus (Lucas) (Decapoda, Brachyura, Grapsidae) reared in the laboratory. Scient. Marina 58 (4): 323-327.

Hyman, O.W. 1924. Sudies on larvae of crabs of the family Grapsidae. Proc. U.S. nat. Mus. 65 (10): 1-8.

Lebour, M.V. 1944. Larval crabs from Bermuda. Zoologica, New York, 29: 113-128.

Paula, J. 1985. The first zoeal stages of Polibius henslowi Leach, Maja squinado (Herbst), Pachygrapsus marmoratus (Fabricius), and Uca tangeri (Eydoux) (Crustacea, Decapoda, Brachyura). Arq. Mus. Bocage, ser. B, 17 (2): 137-147. 
Rodrigues, M.D. \& A.L. BRossi-GARCIA. 1989. Notas sobre novas ocorrências de Pachygrapsus gracilis (Sausurre, 1858) (Crustacea, Brachyura, Grapsidae) no litoral brasileiro. Ciência e Cultura 41 (1): 63-66.

Schlotterbeck, R.E. 1976. The larval development of the lined shore crab, Pachygrapsus crassipes Randall, 1840 (Decapoda, Brachyura,Grapsidae), reared in the laboratory. Crustaceana 30 (2): 184-200.

VILLALoBos, C.R. 1971. First zoeal stage of Pachygrapsus crassipes Randall. Rev. Biol. Trop. 18: 107-113.

Recebido em 07.XI.1996; aceito em 18.IX.1997. 